\title{
Molecular identification of proline-rich protein genes induced during root formation in grape (Vitis vinifera L.) stem cuttings
}

\author{
P. THOMAS*, M. M. LEE \& J. SCHIEFELBEIN \\ Department of Molecular, Cellular, and Developmental Biology, University of Michigan, Ann Arbor, MI 48109, USA
}

\begin{abstract}
Vegetative reproduction relies on the initiation of new plant organs in response to environmental changes. The rapid formation of roots, and ultimately whole plants, from stem

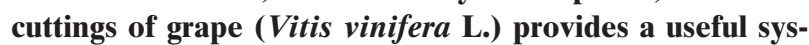
tem to investigate the physiological and molecular basis of organ initiation during vegetative reproduction. In the present study the differential RNA display technique was employed to identify two genes, $V v P R P 1$ and $V v P R P 2$, that are induced in stem cuttings of grape during rooting. Each of these genes encodes a distinct type of proline-rich protein that is related to different groups of putative cell wall proteins, and their expression is rapidly induced in stem segments within $6 \mathrm{~h}$ after severing. Further, each gene's transcript becomes most concentrated in the basal portion of the stem segment in the region of new root formation. Induction of these genes is not significantly enhanced by indole-3-acetic acid (IAA) treatment, and the expression of the $V v P R P 1$ gene, but not the $V v P R P 2$ gene, is wound-inducible. These results suggest that these $V v P R P$ genes play an important role in the initiation of new roots on grape stem cuttings, perhaps by altering the cell wall mechanical properties to enable root emergence.
\end{abstract}

Key-words: cell wall; differential display; proline-rich proteins; root development; vegetative propagation; wounding.

\section{INTRODUCTION}

Vegetative reproduction is a non-sexual mode of reproduction displayed by many plants in response to particular environmental conditions. In plant species that are able to be propagated by cuttings, one of the critical events following the severing of stem segments is the initiation and development of a functional root system. A

Correspondence: John Schiefelbein. Fax: +1 734647 0884; e-mail: schiefel@umich.edu

*Present address: Division of Biotechnology, Indian Institute of Horticultural Research, Hessaraghatta Lake, Bangalore 560089 , India. series of morphological changes associated with root formation in cuttings is known to occur, including swelling at the basal end of the stem segment, callus formation, root primordia development, and finally root emergence (Jarvis 1986; Hartmann et al. 1997). It is likely that numerous molecular events occur within the cuttings to generate these morphological changes, but little is currently known about the molecular basis of adventitious rooting in stem cuttings.

To date, only a few genes have been identified that are associated with the general process of adventitious root formation. In one of the earliest studies, Dhindsa, Dong \& Lalonde (1987) detected changes in the pattern of protein and mRNA accumulation during auxin-induced root formation from mung bean hypocotyl. In another set of studies, auxin treatment was used to detect differential gene expression in loblolly pine, apple, and almond microcuttings (Caboni et al. 1997; Goldfarb et al. 1997). Similarly, Hutchison et al. 1999) identified differential expression of auxin-inducible $\alpha$-expansin mRNA in hypocotyl stem cuttings from loblolly pine seedlings, and the induction of $\alpha$ expansins was suggested to be involved in adventitious root formation. Screening a cDNA library constructed from auxin-treated juvenile petiole cuttings of English ivy, Woo, Hackett \& Das (1994) identified a proline-rich protein (PRP) cDNA clone differentially expressed in petioles from mature and juvenile stages which differ in rooting competence.

Grapes, commercially important as a fruit and wine crop, are exclusively propagated vegetatively, and their stem cuttings vigorously root in response to severing (Hartmann et al. 1997). Furthermore, recent work has defined many of the physiological and environmental factors that influence rooting of grape stem cuttings (Thomas 1998). Thus, grape cuttings represent a potentially attractive system for studying the molecular basis of adventitious rooting. As a starting point for this goal, we sought to isolate genes associated with adventitious rooting by identifying mRNAs that accumulate in stem cuttings during the rooting period. In this report, we describe our use of the sensitive differential display technique (Liang \& Pardee 1992) to isolate and characterize two genes encoding distinct proline-rich proteins that are induced during root formation in grape cuttings. 


\section{MATERIALS AND METHODS}

\section{Plant material}

Grape (Vitis vinifera L.) cv. Arka Neelamani was used for the present study. Single nodal soft wood cuttings were prepared from either in vitro-grown plants 5-6 weeks into the subculture period or from soil-grown plants at 1.52 months after planting. The cuttings and the in vitro stock were grown on Murashige and Skoog (MS) medium containing $3 \%$ sucrose and $1.0 \mu \mathrm{M}$ indole-3-acetic acid (IAA) with subculturing at 1-3 month intervals as previously described (Thomas 1997).

\section{RNA extraction and differential display}

RNA was extracted from the various tissues essentially as described by Loulakakis, Roubelakis-Angelakis \& Kanellis (1996) and modified as described by Thomas \& Schiefelbein (2002). The two sources of RNA for the differential display technique were: (1) stem tissue from leafy single nodal cuttings (derived from in vitro-grown stock) grown for $48 \mathrm{~h}$ in the in vitro media described above; and (2) stem tissue from the in vitro-grown stock.

Differential display reverse transcriptase (RT)-polymerase chain reaction (PCR) was performed using the RNAimage kit 1 from GenHunter Corporation (Nashville, TN, USA). The RNA samples $(50 \mu \mathrm{g})$ were first treated with RNAse-free DNAse 1 in the presence of 10 units of RNAse inhibitor RNAsin (Promega, Madison, WI, USA) for $30 \mathrm{~min}$ at $37^{\circ} \mathrm{C}$, extracted with phenol-chloroform $(3: 1)$ and ethanol precipitated in presence of sodium acetate (Reuber \& Ausubel 1995). For reverse transcription, $2.0 \mu \mathrm{L}$ of a $0.1 \mu \mathrm{g} \mu \mathrm{L}^{-1}$ fresh dilution was used in a $20 \mu \mathrm{L}$ reaction $(4 \mu \mathrm{L} 5 \times$ RT buffer, $1.6 \mu \mathrm{L} 250 \mu \mathrm{M}$ dNTP, $2 \mu \mathrm{L}$ of $\mu \mathrm{M}$-anchored primer and 100 units of Moloney murine leukemia virus RT) as per the kit (GenHunter Corporation). This cDNA was PCR amplified using eight different arbitrary primers in duplicate $25 \mu \mathrm{L}$ reactions including $2 \mu \mathrm{Ci}$ $\alpha_{-}{ }^{33} \mathrm{P}$ dATP $\left(3000 \mathrm{Ci} \mathrm{mM}^{-1} ; 10 \mu \mathrm{Ci} \mu \mathrm{L}^{-1}\right.$; ICN Biomedicals, Irvine, CA, USA). Cycling conditions were: $94{ }^{\circ} \mathrm{C}$ for $30 \mathrm{~s}$; $40{ }^{\circ} \mathrm{C}$ for $2 \mathrm{~min} ; 72^{\circ} \mathrm{C}$ for $30 \mathrm{~s}$ for 40 cycles followed by a final extension at $72{ }^{\circ} \mathrm{C}$ for $5 \mathrm{~min}$ and cooling to $4{ }^{\circ} \mathrm{C}$ using a MJ Research (Waltham, MA, USA) thermocycler. Differentially expressed sequences were detected by separating the PCR products in a $6 \%$ polyacrylamide gel with paired sets of reactions (RNA from control versus rootinginduced samples) run side by side and subjecting the gel to autoradiography. The cDNA bands of interest were isolated by boiling gel slices in $100 \mu \mathrm{L}$ distilled water for $10 \mathrm{~min}$ and precipitating DNA in the presence of $0.3 \mathrm{M}$ sodium acetate, 4.5 volumes of ethanol and $50 \mu \mathrm{g}$ glycogen. The redissolved cDNA was then used for PCR amplification in a $40 \mu \mathrm{L}$ reaction using the same set of anchored and arbitary primers that generated the original band. The reamplified cDNA bands were gel-purified using the QIAquick kit (Qiagen, Valencia, CA, USA) and cloned into the PCR-Trap vector (GenHunter Corporation) via blunt end ligation.

\section{Northern hybridization}

RNA blot (Northern) hybridization analysis was conducted with $10 \mu \mathrm{g}$ samples of RNA electrophoresed in formaldehyde agarose gels (1\%) and blotted onto GeneScreen (DuPont NEN Research Products, Inc., Boston, MA, USA) membranes using $10 \times$ sodium salt citrate (SSC) as per manufacturers protocol. The membranes were exposed to $\alpha-{ }^{32} \mathrm{P}-$ dATP labelled gene-specific DNA probes prepared using a random priming kit (Roche Molecular Biochemicals, Indianapolis, IN, USA). Prehybridization and hybridization were carried out in $0.25 \mathrm{M}$ phosphate buffer ( $\mathrm{pH} 6.8$ ), $1 \mathrm{mM}$ ethylenediaminetetraacetic acid, $1.0 \%$ casein, $7 \%$ sodium dodecyl sulphate and $50 \%$ formamide at $42{ }^{\circ} \mathrm{C}$ for $20 \mathrm{~h}$ essentially as described in Sambrook, Fritsch \& Maniatis (1989).

\section{DNA sequencing and analysis}

DNA sequencing was done using the BigDye ${ }^{\mathrm{TM}}$. Terminator cycle sequencing Ready reaction kit (Perkin-Elmer
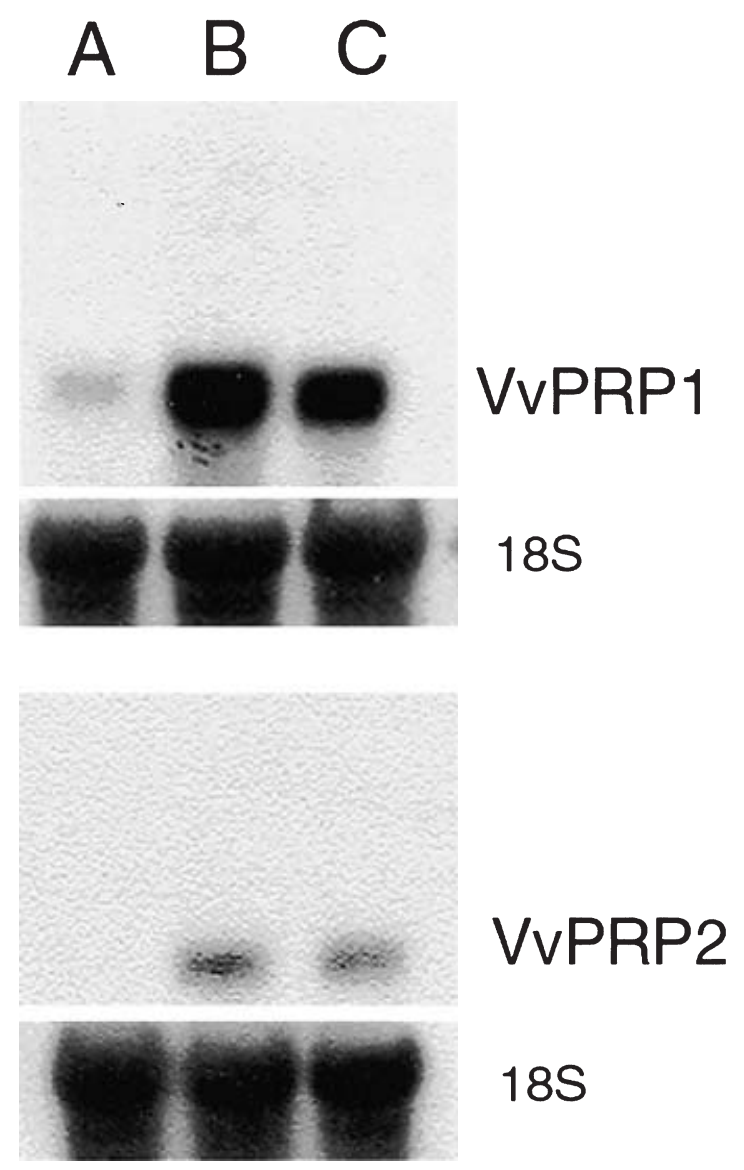

Figure 1. Northern blot analysis of $V v P R P 1$ and $V v P R P 2$ in stem tissue. Total RNA was isolated from untreated stems (A), stems from cuttings bearing a leaf and incubated for $48 \mathrm{~h}$ in growth medium (B), or stems from leafless cuttings incubated for $48 \mathrm{~h}$ in growth medium $(\mathrm{C})$. Following removal of the PRP probe, the membranes were exposed to an $18 \mathrm{~S}$ rRNA probe to serve as a loading control. 
Applied Biosystems, Foster City, CA, USA) containing Ampli Taq. The reaction products were resolved and the sequence was determined using as ABI Prism DNA sequencer. DNA sequences were analysed using GENETYXMac software (Genetyx Corporation, Tokyo, Japan).

\section{5' RACE technique}

The 5' RACE (rapid amplification of cdna ends) was performed by employing a 5'/3' RACE kit (Roche Molecular Biochemicals) using gene specific primers (GSP) which were designed based on the $3^{\prime}$ end sequence information. First strand cDNA was synthesized using avian myeloblastosis virus reverse transcriptase, DNAse treated total RNA
$(2 \mu \mathrm{g})$ from rooting-induced leafy cuttings, and a genespecific primer near the $3^{\prime}$ end of mRNA (excluding the poly A tail). The cDNA was purified using the High Pure PCR purification kit (Roche Molecular Biochemicals).

\section{RESULTS \\ Identification of Vitis vinifera genes induced in grape cuttings}

Leafy stem cuttings from grape (Vitis vinifera L.) cv. Arka Neelamani incubated in our culture medium (see Materials and methods) begin to exhibit the first signs of root formation (e.g. swelling at the basal end) within 2-3 d after

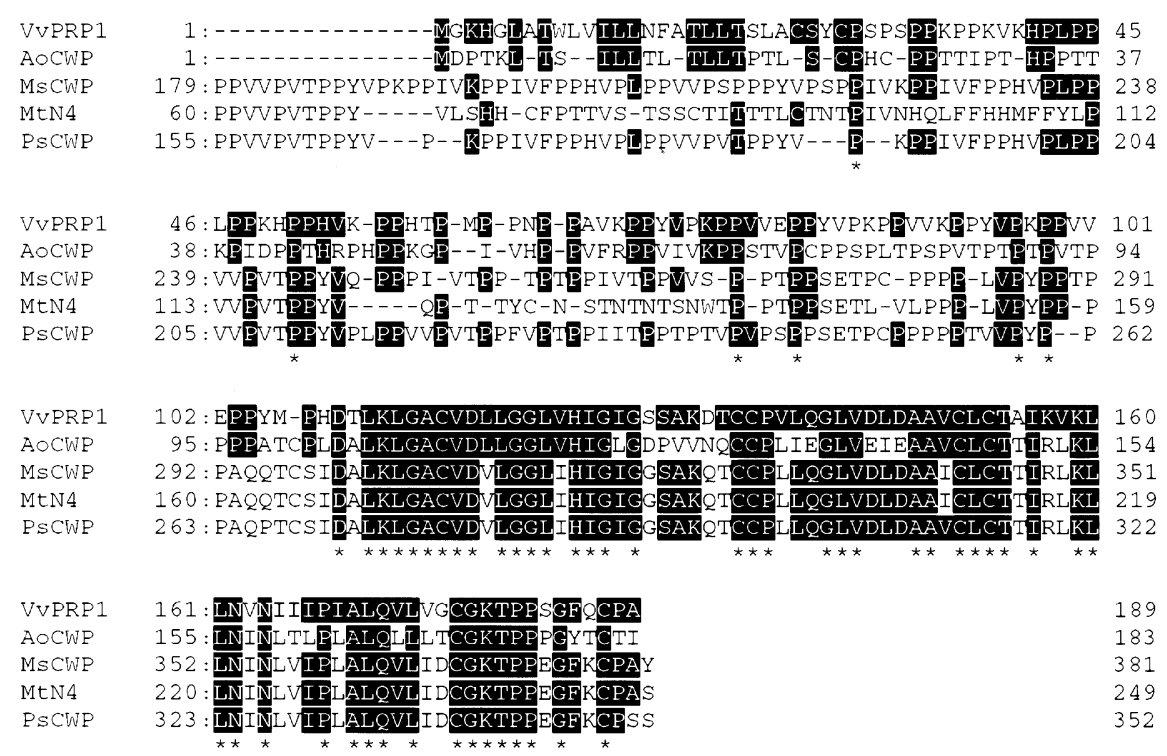

VVPRP2

Vvgrip15

Vvgrip13

Vvgrip4

Vvgrip3

VVPRP2

Vvgrip15

Vvgrip13

Vvgrip4

Vvgrip3

VVPRP2

Vvgrip15

Vvgrip13

Vvgrip4

Vvgrip3

VVPRP2

Vvgrip15

vvgrip13

Vvgrip4

Vvgrip3
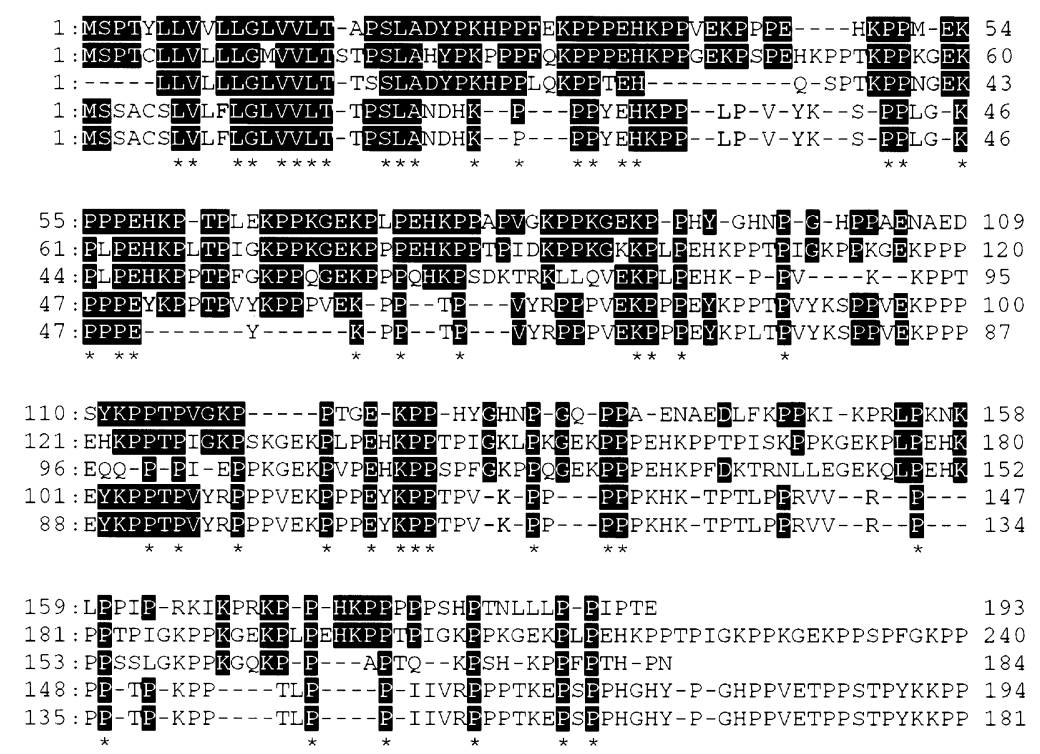

\section{-EIPTE}

193 PHGHY-P-GHPPVETPPSTPYKKPP 194

$194:$

Vvgrip4

241 : TGEKPPHYGHTPGHPPAHSYKPPQKIKPPPTPPHKPPHKPPSPTYPN

195 : TPEKKP-W- -AP-H-HKH-FKAPPPIHAN

vvgrip 3
Figure 2. Deduced amino acid sequence of VvPRP1 and its comparison to related proteins. Residues shared between VvPRP1 and at least one of the other proteins are shaded. Asterisks indicate residues that are present in all five of the sequences. Abbreviations and accession numbers are: AoCWP, Asparagus officinalis proline-rich cell-wall-like protein (X82413); MsCWP, Medicago sativa proline-rich cell wall protein (S52985); MtN4, Medicago truncatula protein (Y15372); PsCWP, Pisum sativum probable cell wall protein (T06482).
Figure 3. Deduced amino acid sequence of VvPRP2 and its comparison to related proteins. Residues shared between VvPRP2 and at least one of the other proteins are shaded. Asterisks indicate residues that are present in all five of these sequences. Accession numbers for the grip (grape ripening induced) sequences from Vitis vinifera are: Vvgrip15 (AJ237984), Vvgrip13 (AJ237983), Vvgrip4 (AJ237982),

204 Vvgrip3 (AJ237981). 
severing. Therefore, to identify genes expressed during root establishment, we isolated stem RNA from 48-hour-old leafy cuttings and stem RNA from untreated control stock and used them in a series of differential display reactions (see Materials and methods for details). Several prominent cDNA fragments were consistently and specifically generated in samples derived from the cuttings. In the present article, we focus on two genes encoding distinct proline-rich proteins from Vitis vinifera. We have designated these genes $V v P R P 1$ and $V v P R P 2$.

To confirm the differential expression of these genes in the $48 \mathrm{~h}$ cuttings versus untreated stems, we used the cDNA fragments as probes in Northern hybridization experiments (Fig. 1). Each probe exhibited the strongest hybridization signal in lanes containing RNA from $48 \mathrm{~h}$ leafy cuttings, indicating that the expression of each gene is significantly induced in the cuttings (Fig. 1). These genes were also induced in leafless cuttings, albeit at a lower level (Fig. 1), which correlates with the lower rooting frequency observed in leafless cuttings (P.T and J.S., unpublished observations) and suggests these genes are associated with the rooting process.

\section{Sequence analysis of the VvPRP1 and VVPRP2 genes}

The two partial cDNA clones obtained from the differential display were sequenced and used to isolate full-length cDNA clones via the $5^{\prime}$ RACE technique. The full-length cDNA sequences of $V v P R P 1$ and $V v P R P 2$ were determined and deposited in the GenBank database under the accession numbers AY046416 and AY046417, respectively. The nucleotide and deduced amino acid sequences of $V v P R P 1$ and $V v P R P 2$ were subsequently used in BLAST searches (Altschul et al. 1997) of the sequence databases. The VvPRP1 appears to be identical to partial expressed sequence tags (ESTs) isolated from Vitis vinifera and Vitis riparia (accession numbers AF220196, AF220197, AF176653 AF176654), whereas the $V v P R P 2$ sequence has not been previously reported.

The VvPRP1 protein is 189 amino acids in length, including $43(23 \%)$ proline residues (Fig. 2). The prolines are concentrated in the N-terminal half, which includes five tandem copies of the repeat PPXVK/EPPXXPX. There is a putative signal sequence at the $\mathrm{N}$-terminus containing a hydrophobic-rich segment of 24 residues. The VvPRP1 protein sequence is most similar (44-50\% identical) to a set of putative cell wall-localized proline-rich proteins isolated from several different plant species (Fig. 2). Less-related proteins are also present in Arabidopsis and rice (data not shown). Interestingly, the greatest region of identity is located in the C-terminal half of the protein, which is not the proline-rich portion (Fig. 2).

The VvPRP2 protein possesses 193 residues, and 63 of these $(33 \%)$ are proline (Fig. 3). The N-terminal half contains six complete and several incomplete copies of the repeat $\mathrm{PP}(\mathrm{P}) \mathrm{XXK}$. Like the VvPRP1, the VvPRP2 possesses a hydrophobic domain at the $\mathrm{N}$ terminus that may represent a signal sequence. The VvPRP2 is most similar (36-59\% identical) to four proline-rich proteins encoded by grape ripening induced (GRIP) genes isolated from a Vitis vinifera berry cDNA library (Fig. 3; Davies \& Robinson 2000). The most similar protein detected outside of Vitis is from an ENOD-like transcript from Cladrastis kentukea (GenBank no. AF289098). Taken together, these sequences analyses indicate that the $V v P R P 1$ and $V v P R P 2$ genes encode distinct proline-rich cell wall proteins.

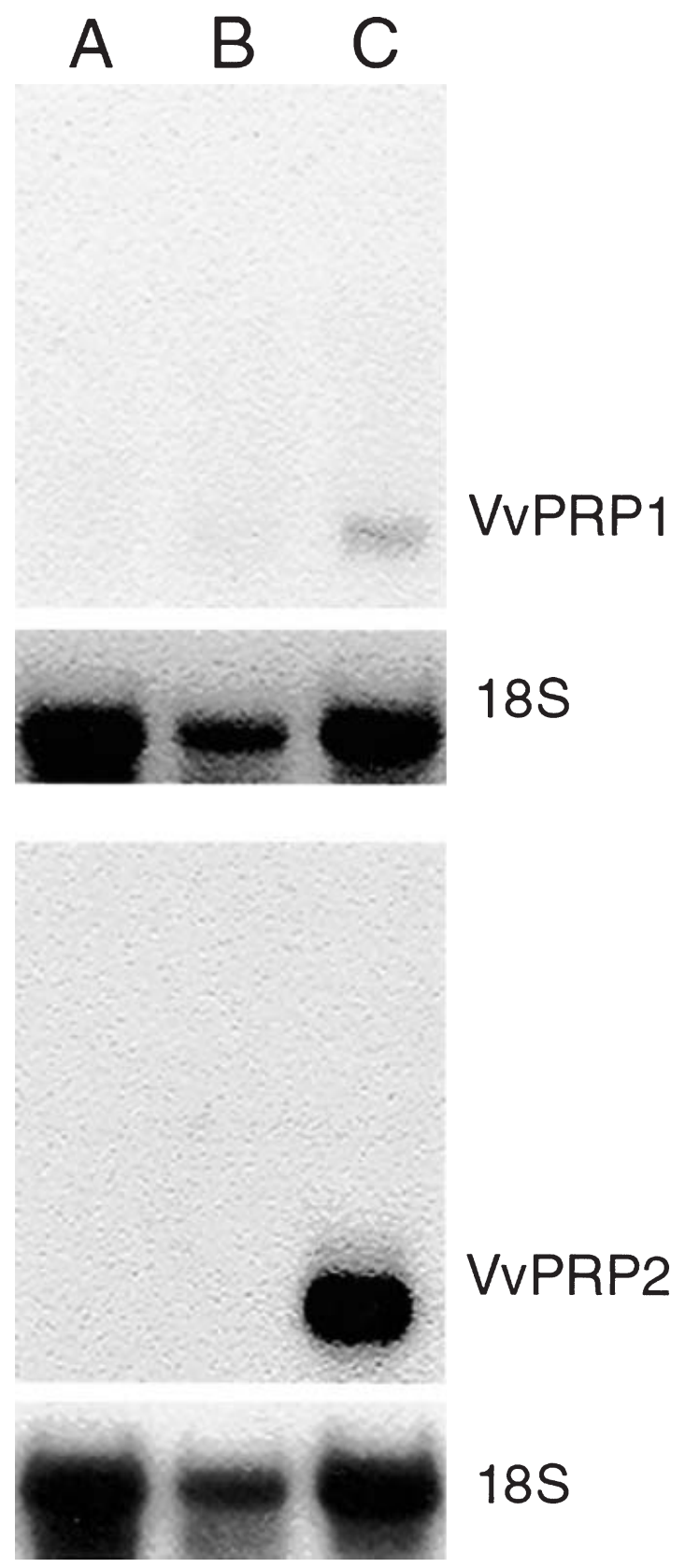

Figure 4. Northern blot hybridization analysis of $V v P R P 1$ and $V v P R P 2$ genes in normal grape plants. RNA was isolated from the shoot tips (A), leaves (B), or roots (C) from 2-month-old plants grown in soil. Following removal of the PRP probes, the membranes were exposed to an $18 \mathrm{~S}$ rRNA probe to serve as a loading control. 


\section{Expression of $V v P R P 1$ and $V v P R P 2$ in grape plants and cuttings}

The expression of $V v P R P 1$ and $V v P R P 2$ was investigated in various organs of soil-grown plants. Northern hybridization analysis showed that each gene is preferentially expressed in root tissue and is not detected in either shoot tips (including meristems and young stems) or leaf tissue (Fig. 4). Thus, each gene is likely to be involved in the development and/or physiology of roots in normal (untreated) plants.

To examine the induction of the PRP genes in grape cuttings in detail, we analysed their expression in different parts of the cuttings (lower stem, upper stem, petiole, and leaf) at two different times (6 and $96 \mathrm{~h})$ after severing (Fig. 5). This experiment showed that expression of each of the $V v P R P$ genes is induced within $6 \mathrm{~h}$ after severing, with the highest expression level in the stem and petiole parts of the cuttings (Fig. 5B). At $96 \mathrm{~h}$ post-severing, each of the $V v P R P s$ is preferentially expressed in the lower portion of the stems (Fig. 5C), which includes the rooting region of the cutting. In this experiment, we also detected a low level of VvPRP expression in the newly emerging roots in 8-day-old cuttings, but no significant expression in the new sprouts on 14-day-old cuttings (Fig. 5D \& E). Together, these results further implicate the
VvPRP1 and VvPRP2 in the process of adventitious root formation.

Having established that the cuttings exhibit induced expression of the $V v P R P 1$ and $V v P R P 2$ genes within $6 \mathrm{~h}$ after severing, we wished to define the earliest time of gene induction. Therefore, we analysed gene expression in stems from 1-, 3-, and 6-hour-old cuttings (Fig. 6). Induction of $V v P R P 1$ expression was detected in 1-hour-old cuttings and induction of $V v P R P 2$ expression was first detected in 6-hour-old cuttings (Fig. 6), showing that severing has a rapid effect on the accumulation of these RNAs in the cuttings.

Auxin is believed to be a primary regulator of adventitious root formation in stem cuttings (Jarvis 1986). We therefore examined whether exposure of the cuttings to auxin (10 $\mu \mathrm{M}$ IAA) might enhance the induction of the PRP genes. In general, we found no significant difference in the level of PRP gene expression in cuttings treated with IAA versus distilled water, although a slight effect of IAA was observed for VvPRP1 in 1-hour-old cuttings (Fig. 6). These results suggest that the induction of $V v P R P 1$ and $V v P R P 2$ gene expression is not auxin-sensitive.

We next tested the ability of specific factors in the growth medium to induce expression of the $V v P R P$ genes. Our normal growth medium contains MS salts, sucrose, and IAA. Therefore, we examined $V v P R P$ expression in stem

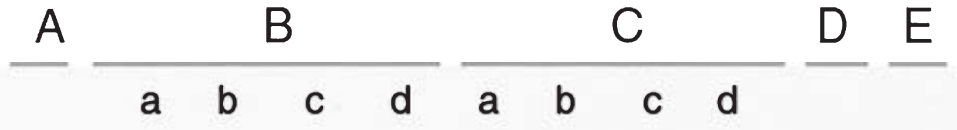

$18 S$

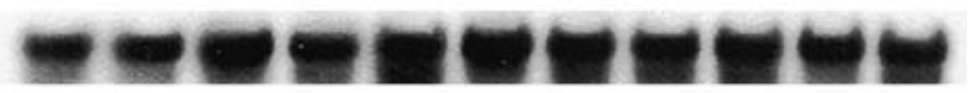

VvPRP1

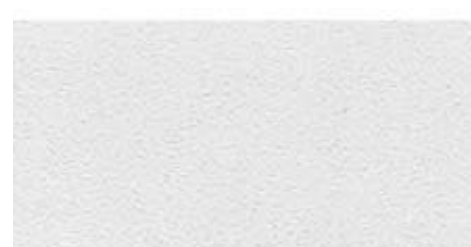

\section{VvPRP2}

$18 \mathrm{~S}$

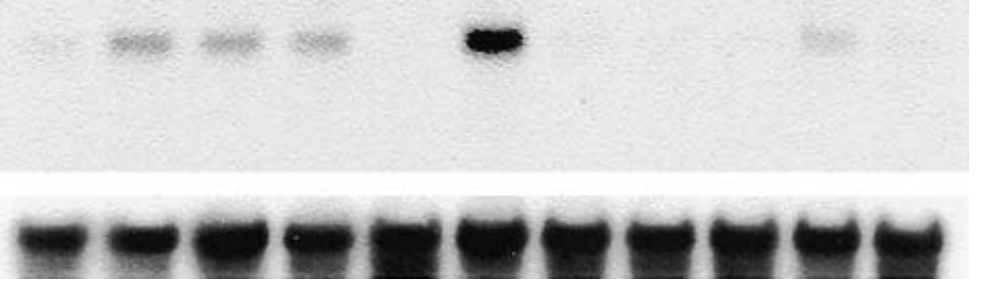

Figure 5. Northern blot analysis of the spatial and temporal expression of $V v P R P 1$ and $V v P R P 2$ in grape cuttings. RNAs were prepared from untreated stems (A), from the lower stem (a), upper stem (b), petiole (c), or leaf (d) from 6hour-old cuttings (B) or from 96-hour-old cuttings $(\mathrm{C})$, from the emerging roots on 8 -day-old cuttings (D), and from new sprouts on 14-day-old cuttings (E). Following removal of the PRP probes, the membranes were exposed to an $18 \mathrm{~S}$ rRNA probe to serve as a loading control. 


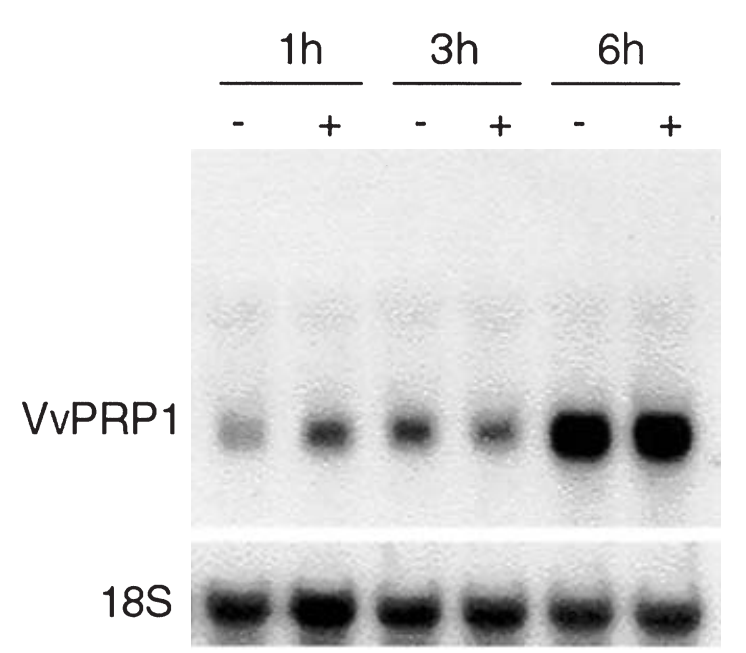

VvPRP2

$18 \mathrm{~S}$
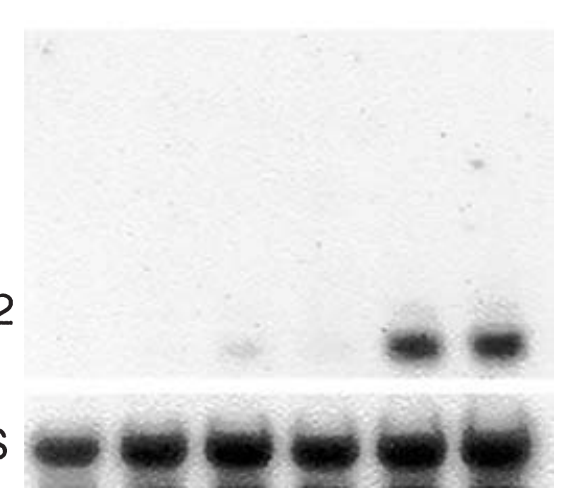

Figure 6. Northern blot analysis of $V v P R P 1$ and $V v P R P 2$ gene expression in cuttings during the initial $6 \mathrm{~h}$ after severing. RNA was isolated from the stems of 1-, 3-, or 6-hour-old cuttings exposed to no IAA (-) or to $10 \mu \mathrm{M}$ IAA (+) in the medium. Following removal of the PRP probes, the membranes were exposed to an $18 \mathrm{~S}$ rRNA probe as a loading control.

cuttings which had been incubated in media containing $10 \mu \mathrm{M}$ IAA alone, $3 \%$ sucrose alone, $1 \times$ MS salts alone, or none of these. We discovered that stem cuttings from each of these treatments accumulated similar amounts of $V v P R P 1$ and $V v P R P 2$ RNA (Fig. 7). These results suggest that induction of the $V v P R P 1$ and $V v P R P 2$ genes in the cuttings is not merely due to a specific component of the growth media.

\section{Effect of wounding on expression of the VvPRP genes}

Wounding is an unavoidable outcome of the preparation of the stem cuttings. We wished to determine whether the induction of the $V v P R P$ genes that we observe in cuttings may be due to a wounding effect rather than to developmental changes that are specific to the stem cuttings. Therefore, we wounded the surface of stem and leaf tissue of intact plants by rubbing them with quartz sand and, after $6 \mathrm{~h}$, we examined $V v P R P 1$ and $V v P R P 2$ expression by Northern blotting. The expression of the $V v P R P 1$ gene was

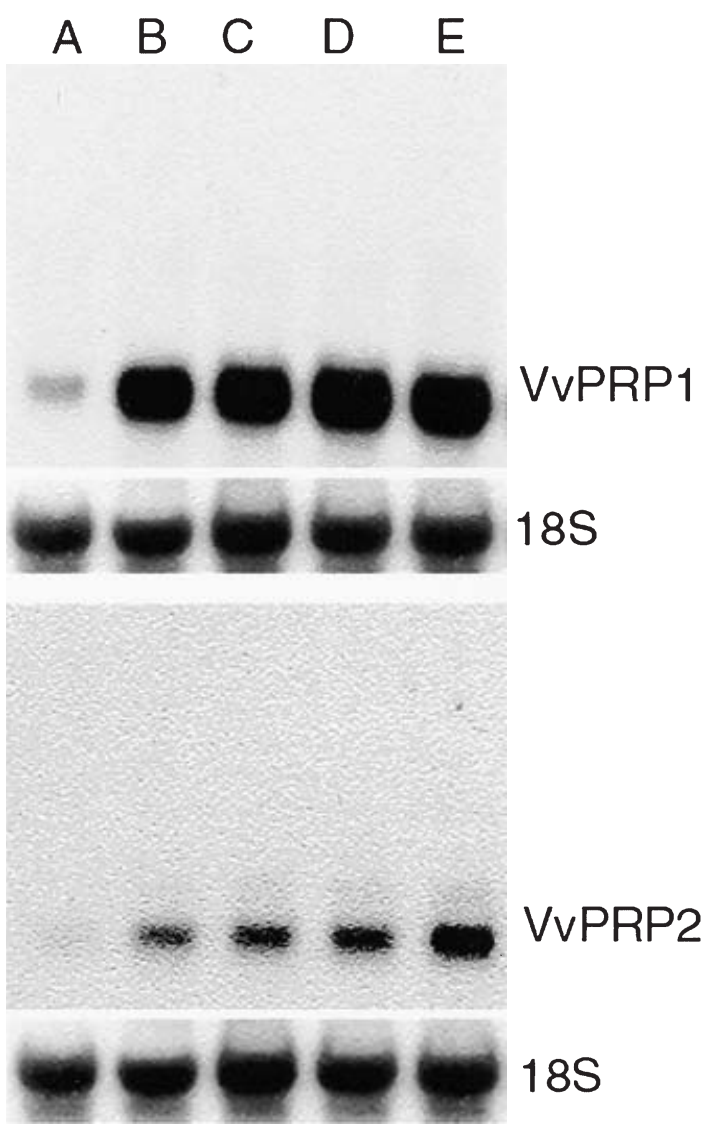

Figure 7. Northern blot hybridization analysis of $V v P R P 1$ and $V v P R P 2$ gene expression in stems from intact plants (A) or 6-hourold stem cuttings (B-E). The stem cuttings had been incubated in media containing either distilled water (B), $10 \mu \mathrm{M}$ IAA (C), $3 \%$ sucrose (D), or $1 \times$ MS salts (E). Following removal of the PRP probes, the membranes were exposed to an $18 \mathrm{~S}$ rRNA probe to serve as a loading control.

significantly induced in the wounded stem and leaf, and the level was comparable to the induction observed in stem cuttings (Fig. 8). However, VvPRP2 gene expression was not affected by the wounding treatment in the stems and leaves (Fig. 8). This indicates that $V v P R P 1$ is a woundinducible gene but $V v P R P 2$ is not.

\section{DISCUSSION}

Stem cuttings from grape plants undergo dramatic developmental changes following severing, including the rapid formation of new roots at their basal end. In this study, we employed the differential display technique to identify genes that are induced in these stem cuttings during the period of root initiation. We have sequenced and characterized two different genes, $V v P R P 1$ and $V v P R P 2$, in detail. We found that each of these genes is preferentially expressed in roots of normal (soil-grown) grape plants and their expression is rapidly induced in stem cuttings during the period and in the location of new root formation. Furthermore, their level of induction is 

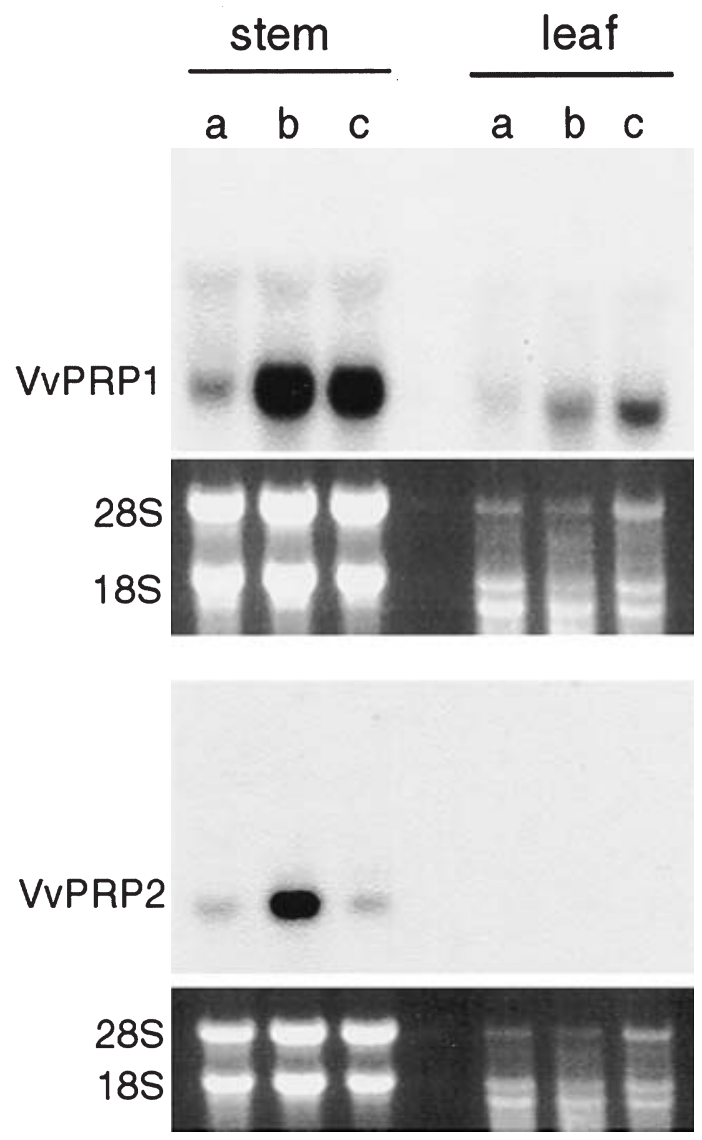

Figure 8. $V v P R P$ gene expression in wounded stems and leaves. Northern blot analysis was conducted with total RNA isolated from the stem or leaf of: untreated plants (a), 24-hour-old cuttings (b), or plants abrased with quartz sand $6 \mathrm{~h}$ prior to extraction (c). Following removal of the PRP probes, the membranes were exposed to an 18S rRNA probe to serve as a loading control.

related to rooting ability, because leafless stem cuttings, which have a reduced rooting frequency (P.T and J.S., unpublished observations), exhibit a lower level of induction than leafy stem cuttings. To our knowledge, these genes represent the first to be identified as induced during the period of root formation in grape cuttings. Therefore, this study establishes a foundation for the molecular dissection of root formation during vegetative propagation in grape.

The $V v P R P 1$ and $V v P R P 2$ genes encode distinct types of proline-rich proteins. Proline-rich proteins, including the well-characterized PRPs, represent a major category of cell wall proteins in plants and are involved in a variety of developmental processes and environmental responses (Showalter 1993; Cassab 1998). The VvPRP1 and VvPRP2 proteins are most similar to two distinct groups of prolinerich proteins from several different plant species.

The VvPRP1 gene appears to encode the same protein as partial ESTs isolated from a grape berry library, and based on information about these from the databases (accession numbers AF220196, AF220197, AF176653
AF176654), it is also expressed in flower buds and is associated with freezing tolerance. The $V v P R P 1$ is similar to a salt-inducible alfalfa gene (Deutch \& Winicov 1995), an asparagus gene whose expression rapidly declines in harvested spear tips (King et al. 1996), and a root noduleinduced gene (MtN4) from Medicago truncatula (Gamas et al. 1996). Considering that we have shown that VvPRPI is wound-inducible (Fig. 8), we suggest that the VvPRP1 protein is a member of a class of proline-rich proteins that help modify the cell wall in response to various developmental or physiological stresses.

The $V v P R P 2$ is most similar to four proline-rich proteins encoded by grape ripening induced (GRIP) genes isolated by differential screening from a ripening berry cDNA library (Davies \& Robinson 2000). Because it is not woundinducible, the VvPRP2 is likely to be a cell wall protein that is required for specific developmental processes, such as root initiation.

A possible role of VvPRP1 and VvPRP2 in stem cuttings may be to increase the plasticity of the cell walls or its reinforcement thus enabling cells to withstand the mechanical pressure involved in the eruption of the root meristem through the surrounding tissues. A similar function is suggested for the structural cell wall proteins involved in lateral root development. The tobacco hydroxyproline-rich glycoprotein HRGPnt3 is specifically expressed in subsets of the pericycle and endodermal cells from which the lateral root are initiated and is considered to be involved in the hardening of the cell wall at the root tip, providing the mechanical strength required for penetrating through the cortex and epidermis of the main root (Keller \& Lamb 1989). Expression of the soybean hydroxyproline-rich glycoprotein SbHRGP is confined to the epidermal cells of the zone from which the lateral roots emerge and is suggested to be involved in cell wall reformation that may be required for the initiation and development of the lateral root from the parental root (Ahn et al. 1996). The $V v P R P$ gene expression we have observed coincides with the period of root primordia initiation and growth through the cortical and epidermal layers of the stem tissue, consistent with this possible role in cell wall reformation or reinforcement.

Auxin is known to be a hormonal regulator of adventitious root formation in stem cuttings (Jarvis 1986). Consistent with this, some PRP genes involved in lateral root formation or root hair production show positive regulation of mRNA expression by auxin supply (Ebener et al. 1993; Neuteboom et al. 1999; Bernhardt \& Tierney 2000). Nevertheless, we did not observe a significant effect of IAA treatment on the VvPRP expression in grape cuttings. This suggests that auxin does not enhance rooting in grape cuttings via induction of the VvPRP genes. On the other hand, monitoring the expression pattern during the initial $6 \mathrm{~h}$ incubation period showed a slightly higher level of expression of $V v P R P 1$ mRNA in IAA-treated cuttings at $1 \mathrm{~h}$. Thus, it is still possible that auxin is a regulator of these genes in a particular time-dependent or a concentrationdependent manner. 


\section{ACKNOWLEDGMENTS}

The grape 'Arka Neelamani' culture was provided by the Indian Institute of Horticultural Research (ICAR), Bangalore, India. This work was supported by the University of Michigan and by an Overseas Associateship Award to P.T. by the Department of Biotechnology, Ministry of Science and Technology, Government of India.

\section{REFERENCES}

Ahn J.H., Choi Y., Kwon Y.M., Kim S.-G., Choi Y.D. \& Lee J.S. (1996) A novel extensin gene encoding a hydroxyproline-rich glycoprotein requires sucrose for its wound-inducible expression in transgenic plants. Plant Cell 8, 1477-1490.

Altschul S.F., Madden T.L., Schaffer A.A., Zhang J., Zhang Z., Miller W. \& Lipman D.J. (1997) Gapped BLAST and PSIBLAST: a new generation of protein database search programs. Nucleic Acids Research 25, 3389-3402.

Bernhardt C. \& Tierney M.L. (2000) Expression of AtPRP3, a proline-rich structural cell wall protein from Arabidopsis, is regulated by cell-type-specific developmental pathways involved in root hair formation. Plant Physiology 122, 705-714.

Caboni E., Lauri P., Watillon B. \& Damiano C. (1997) Isolation of mRNA species related to the rooting induction in almond and apple through the differential display technique. Biologia Plantarum 39, 99-104.

Cassab G.I. (1998) Plant cell wall proteins. Annual Review of Plant Physiology and Plant Molecular Biology 49, 281-309.

Davies C. \& Robinson S.P. (2000) Differential screening indicates a dramatic change in mRNA profiles during grape berry ripening. Cloning and characterization of cDNAs encoding putative cell wall and stress response proteins. Plant Physiology 122, 803812.

Deutch C.E. \& Winicov I. (1995) Post-transcriptional regulation of a salt-inducible alfalfa gene encoding a putative chimeric proline-rich cell wall protein. Plant Molecular Biology 27, 411-418.

Dhindsa R.S., Dong G. \& Lalonde L. (1987) Altered gene expression during auxin-induced root development from excised mung bean seedlings. Plant Physiology 84, 1148-1153.

Ebener W., Folwer T.J., Suzuki H., Shaver J. \& Tierney M.L. (1993) Expression of DcPRP1 is linked to carrot storage root formation and is induced by wounding and auxin treatment. Plant Physiology 101, 259-265.

Gamus P., Niebel F.C., Lescure N. \& Cullimore J. (1996) Use of a subtractive hybridization approach to identify new Medicago truncatula genes induced during root nodule development. Molecular Plant Microbe Interactions 9, 233-242.

Goldfarb B., Lian Z., Lanz-Garcia C. \& Whetten R. (1997) Auxininduced gene expression during rooting of loblolly pine stem cuttings. In The Biology of Root Formation and Development (eds A. Altman \& F. Waisel), pp. 163-167. Plenum Press, New York, USA.

Hartmann K.T., Kester D.E., Davies F.T. \& Geneve R.L. (1997) Plant Propagation-Principles and Practices, 6th edn. Prentice Hall, Englewood Cliffs, NJ, USA.
Hutchison K.W., Singer P.B., McInnis S., Diaz-Sala C. \& Greenwood M.S. (1999) Expansins are conserved in conifers and expressed in hypocotyls in response to exogenous auxin. Plant Physiology 120, 827-832.

Jarvis B.C. (1986) Endogenous control of adventitious rooting in non-woody cuttings. In New Root Formation in Plants and Cuttings (ed. M.B. Jackson), pp. 191-222. Martinus-Nijhoff Publishers, Dordrecht, The Netherlands.

Keller B. \& Lamb C.J. (1989) Specific expression of a novel cell wall hydroxyproline-rich glycoprotein gene in lateral root initiation. Genes and Development 3,1639-1646.

King G.A., O'Donoghue E.M., Borst W.M., Davies K.M., Moyle R.L. \& Farnden K.J. (1996) Identification and characterization of an mRNA encoding a proline-rich protein that rapidly declines in abundance in the tips of harvested asparagus spears. Plant and Cell Physiology 37, 706-710.

Liang P. \& Pardee A.B. (1992) Differential display of eukaryotic messenger RNA by means of the polymerase chain reaction. Science 257, 967-971.

Loulakakis K.A., Roubelakis-Angelakis K.A. \& Kanellis A.K. (1996) Isolation of functional RNA from grapevine tissues poor in nucleic acid content. American Journal of Enology and Viticulture 47, 181-185.

Neuteboom L.W., Ng J.M.Y., Kuyper M., Clijdesdale O.R., Hooykaas P.J.J. \& van der Zaal B.J. (1999) Isolation and characterization of cDNA clones corresponding with mRNAs that accumulate during auxin-induced lateral root formation. Plant Molecular Biology 39, 273-287.

Reuber T.L. \& Ausubel F.M. (1995) Differential mRNA display. In Methods in Cell Biology (eds D.W. Galbraith, H.J. Bohnert \& D.P. Borque) Vol. 49, pp. 431-440. Academic Press, New York, USA.

Sambrook J., Fritsch E.F. \& Maniatis T. (1989) Molecular Cloning: a Laboratory Manual, 2nd edn. Cold Spring. Harbor Laboratory Press, Cold Spring Harbor, NY, USA.

Showalter A.M. (1993) Structure and function of plant cell wall proteins. Plant Cell 5, 9-23.

Thomas P. (1997) Increase in clonal propagation of 'Arka Neelamani' grape (Vitis vinifera L.) through induction of axillaries in in vitro layering technique. Indian Journal of Agricultural Science 67, 594-596.

Thomas P. (1998) Humid incubation period and plantlet age influence acclimatization and establishment of micropropagated grapes. In Vitro Cellular and Developmental Biology of Plants 34, 52-56.

Thomas P. \& Schiefelbein J.W. (2002) Improved method for purification of RNA from stem tissue of grapevine and its use in mRNA profiling. American Journal of Enology and Viticulture 53, 231-234.

Woo H.-H., Hackett W.P. \& Das A. (1994) Differential expression of a chlorophyll $a / b$ binding protein gene and a proline rich protein gene in juvenile and mature phase English ivy (Hedera helix). Physiologia Plantarum 92, 69-78.

Received 18 December 2002; received in revised form 23 April 2003; accepted for publication 4 May 2003 